\title{
The case for facilitating competing tender offers
}

\section{Citation}

Bebchuk, Lucian A. 1982. "The Case for Facilitating Competing Tender Offers." Harvard Law Review 95 (5): 1028. https://doi.org/10.2307/1340571.

\section{Permanent link}

http://nrs.harvard.edu/urn-3:HUL.InstRepos:41426670

\section{Terms of Use}

This article was downloaded from Harvard University's DASH repository, and is made available under the terms and conditions applicable to Other Posted Material, as set forth at http:// nrs.harvard.edu/urn-3:HUL.InstRepos:dash.current.terms-of-use\#LAA

\section{Share Your Story}

The Harvard community has made this article openly available.

Please share how this access benefits you. Submit a story.

Accessibility 


\title{
COMMENT
}

\section{THE CASE FOR FACILITATING COMPETING TENDER OFFERS}

\author{
Lucian A. Bebchuk*
}

\begin{abstract}
Last year in this journal, Professors Easterbrook and Fischel advocated a rule that would require management to be passive in the face of a takeover bid, and argued that even resistance that triggers a bidding contest is undesirable. They reasoned that bidding contests curtail the search for takeover targets and thus are ultimately detrimental to shareholder welfare. In this Comment, $\mathrm{Mr}$. Bebchuk maintains that bidding contests are consistent with a substantial level of search, and argues that facilitating competing bids is desirable for both target shareholders and society. Consequently, he endorses regulations that provide time for competing bids, and supports a rule that would allow management to solicit competing bids as long as it does not obstruct the initial or any subsequent tender offer.
\end{abstract}

$I^{n}$ a recent article, 1 Professors Easterbrook and Fischel argue that the facilitation of competing bids in corporate takeovers is undesirable. ${ }^{2}$ Their argument is based on the effect that bidding contests have on the search for takeover targets by prospective acquirers. ${ }^{3}$ Increases in the prices that must be paid for targets, they emphasize, reduce the return on search by prospective acquirers and thus discourage an activity that benefits both targets' shareholders and the economy. ${ }^{4}$ They contend that bidding contests for targets are therefore contrary to the long-run interests of targets' shareholders and of society. Accordingly, even resistance by a target's management that succeeds in triggering a bidding contest and securing a high premium is counterproductive. ${ }^{5}$ Easterbrook and Fischel therefore advocate a rule that would require a target's management to remain passive in the face of a tender offer. ${ }^{6}$

* S.J.D. and Ph.D. candidate, Harvard Law School and Harvard University Department of Economics. I am indebted to Professor Victor Brudney for his advice. I also benefited from comments by Professor Robert Clark and Louis Kaplow on a draft of this Comment.

${ }^{1}$ Easterbrook \& Fischel, The Proper Role of a Target's Management in Responding to a Tender Offer, 94 HARV. L. ReV. I I6I (I98I).

${ }^{2}$ Id. at $1175-80$.

${ }^{3}$ Id. at $1176-80$.

${ }^{4}$ Id. at $1173-74$, I $176-80$.

${ }^{5} \mathrm{Id}$. at $\mathrm{II} 64, \mathrm{II} 75-80$.

${ }^{6} \mathrm{Id}$. at $\mathrm{I} \mathrm{I} 64, \mathrm{I} 20 \mathrm{I}-04$. 
Whether or not bidding contests are desirable, there are strong reasons for opposing defensive tactics, such as creation of antitrust obstacles, that obstruct the resisted offer. ${ }^{7}$ These tactics can be abused, as Easterbrook and Fischel observe, by a management seeking to perpetuate its control. ${ }^{8}$ Obstructing tactics also preclude shareholders from making their own decision whether to accept the offer. ${ }^{9}$ These concerns justify the prohibition of such tactics, ${ }^{10}$ even if Easterbrook's and Fischel's thesis on bidding contests is rejected.

The Easterbrook and Fischel thesis provides the sole ground, however, for barring management's solicitation of a competing bid from a "white knight." 11 This important and widely used tactic cannot be employed by management to avoid a takeover altogether, and it leaves shareholders free to accept any offer; it can only increase the price they will be offered for their shares. The Easterbrook and Fischel thesis also has implications for the regulation of offerors. Various provisions of the Williams Act ${ }^{12}$ and state tender offer statutes regulate tender offers in ways that facilitate competing bids; ${ }^{13}$ if bidding contests are counterproductive, it follows that these provisions are undesirable. ${ }^{14}$

This Comment critically examines Easterbrook's and Fis-

\footnotetext{
${ }^{7}$ Obstructing tactics include creation of antitrust or regulatory obstacles, adoption of an antitakeover charter or bylaw amendments, repurchase of stock, issuance of stock to a friendly party, and litigation against the offeror. See E. Aranow \& H. Einhorn, Tender Offers for Corporate Control 234-76 (I973); A. Fleischer, Tender Offers: Defenses, Responses, and Planning il 3-55 (i98i); M. Lipton \& E. Steinberger, Takeovers \& Freezeouts 296-320 (i978). A relatively new obstructing tactic is the granting of "lock-up" options to a "white knight." See Mobil Corp. v. Marathon Oil Co., [Current Transfer Binder] FED. SEC. L. REP. (CCH) If 98,399, at 92,385 (6th Cir. Dec. 23, I98I).

${ }^{8}$ Easterbrook \& Fischel, supra note I, at II 75; see Gelfond \& Sebastian, Reevaluating the Duties of Target Management in a Hostile Tender Offer, 6o B.U.L. REv. 403 (1980); Gilson, A Structural Approach to Corporations: The Case Against Defensive Tactics in Tender Offers, 33 STAN. L. REv. 819 (I98I); Lynch \& Steinberg, The Legitimacy of Defensive Tactics in Tender Offers, 64 CORNELL L. Rev. 901 (1979).

${ }_{9}$ See Gilson, supra note 8 , at $845-48,856-62$; Lynch \& Steinberg, supra note 8 , at $933-38$.

${ }^{10}$ For a recent, comprehensive argument that these concerns warrant a prohibition of obstructing tactics, see Gilson, supra note 8 .

${ }^{11}$ See Easterbrook \& Fischel, supra note I, at I20I.

12 I5 U.S.C. $\$ \S 78 l(\mathrm{i}), 78 \mathrm{~m}(\mathrm{~d})-(\mathrm{e}), 78 \mathrm{n}(\mathrm{d})-(\mathrm{f})$ (1 976$)$.

13 See infra notes 91-92, 95-96. Primarily, the regulations provide time, which is necessary for making competing offers.

14 The undesirability of regulations that facilitate competing bids is implied by Easterbrook \& Fischel, supra note I, at II79 n.46. A similar view is expressed by Jarrel \& Bradley, The Economic Effects of Federal and State Regulations of Cash Tender Offers, 23 J.L. \& ECON. 37 I (I980).
} 
chel's stimulating analysis and their intriguing thesis. ${ }^{15}$ It argues that facilitating competing tender offers is desirable both to targets' shareholders and to society. Time is essential for competing offers, and such offers will be further facilitated if potential buyers can receive information from the target's management. ${ }^{16}$ This Comment therefore supports a rule of auctioneering that: (I) provides, by regulating offerors, time for making competing bids; and (2) allows incumbent management to solicit such bids by providing information about the target to potential buyers.

Part I discusses the various motives for takeovers, explaining that the motive on which Easterbrook and Fischel concentrate is not the only and probably not even the dominant one. Part II examines a rule of auctioneering from the perspective of targets' shareholders. The analysis shows that the rule does not deny searchers significant rewards relative to search costs and that it thus is consistent with a substantial level of search. Part II then demonstrates that the rule greatly increases premiums in unsolicited takeovers, as well as in negotiated acquisitions. The rule is particularly crucial because, faced with only one potential buyer, a target's dispersed shareholders may be subject to a bargaining disadvantage.

Part III considers a rule of auctioneering from the perspective of social welfare. The rule has several socially beneficial effects, such as the allocation of targets' assets to their most valuable use. Moreover, abandoning the rule in order to enhance rewards for searchers may lead to socially excessive investment in search. On the basis of this analysis, Part IV concludes that competing bids should be facilitated, and outlines the implications of that conclusion for the regulation of offerors and the role of incumbent management.

\section{MOTIVES FOR TAKEOVERS}

Offerors initiating takeover bids may have one or more of the following motives. First, the motive on which Easterbrook and Fischel focus is the prospect of increasing the target's profits by replacing its management. ${ }^{17}$ The new management

\footnotetext{
15 The recent article by Gilson, supra note 8 , at $870-75$, also criticizes the Easterbrook and Fischel view that facilitating competing bids is undesirable. This Comment was written prior to the appearance of Professor Gilson's impressive article. The footnotes to this Comment indicate where the analyses overlap.

16 See infra pp. 1052, I054-55.

17 See Easterbrook \& Fischel, supra note I, at II69-73. This explanation of takeovers was first suggested by Manne, Mergers and the Market for Corporate Control, 73 J. Pol. ECon. i io, II 3 (I965).
} 
may be more dedicated to profit-maximization and less inclined to pursue its own interests, and may thus reduce the level of agency costs. ${ }^{18}$ Alternatively, the new management may be more able and imaginative than the incumbents. ${ }^{19}$ This "managerial gains" explanation is consistent with the evidence that successful tender offers are accompanied by an increase in the combined stock market value of the acquirer and the target. ${ }^{20}$ That evidence, however, does not single out managerial gains as the cause of increased valuation. Although the expectation of managerial gains may explain some or even many takeovers, there is no basis for denying the significance of other motives.

A second and frequent motive for takeovers is the prospect of "synergistic gains." Synergistic gains encompass all increases in the combined future profits of the acquirer and the target that a takeover produces through means other than an improvement in management. The takeover may create economies of scale in production, in marketing, or in control, or it may produce such financial advantages as a reduced cost of capital. ${ }^{21}$ The acquirer may possess some skills or nonpatentable information that are useful to the target. ${ }^{22}$ Finally, the takeover may yield tax savings ${ }^{23}$ or an increase in combined

\footnotetext{
${ }^{18}$ Agency costs refer to the decrease in a company's value caused by the managers' divergence from profit-maximization due to their concern for their own perquisites, leisure, and so forth. Agency costs exist because shareholders are unable to monitor perfectly their agents, the managers. See Jensen \& Meckling, Theory of the Firm: Managerial Behavior, Agency Costs and Ownership Structure, 3 J. Fin. EcoN. 305 (I976).

19 The distinction between gains resulting from a reduction in agency costs and those resulting from superior talent of the new management is important for the following reason. Because agency costs are the result of a deliberate choice by the management to pursue its own interests, the mere threat of a takeover can induce incumbents to be more dedicated to the goal of profit-maximization. Thus, the takeover mechanism reduces agency costs indirectly as well, even in companies that are not subject to a takeover. In contrast, gains from superior talent of the acquirer's management (as well as "synergistic gains") cannot be realized unless the target is actually acquired; no threat can induce the incumbents to perform better than they are able to.

${ }^{20}$ See, e.g., Bradley, Interfirm Tender Offers and the Market for Corporate Control, 53 J. Bus. 345 ( (980); Dodd \& Ruback, Tender Offers and Stockholder Returns, 5 J. Fin. ECon. 35I (I977); Kummer \& Hoffmeister, Valuation Consequences of Cash Tender Offers, 33 J. Fin. 505 (1978); see also Easterbrook \& Fischel, supra note I, at I $186-88$ (discussing this evidence).

${ }^{21}$ See P. Steiner, Mergers: Motives, Effects, Policies 58-69 (1975); Lintner, Expectations, Mergers and Equilibrium in Purely Competitive Securities Markets, 6 Am. Econ. Rev. Ior (I97I) (separate May issue).

22 See Jarrel \& Bradley, supra note 14 , at $382-84$.

${ }^{23}$ See P. Steiner, supra note $2 \mathrm{I}$, at 75-95. The most important sources of tax savings are unused tax-loss carryovers, investment credits, and depreciation allowances that either the acquirer or the target may have and that can be used to reduce
} 
market power, ${ }^{24}$ in which case the synergistic gains - and the resulting increase in the firms' stock market value - do not reflect any social gains.

Synergistic gains have been recognized by many commentators as an important and pervasive motive for takeovers. ${ }^{25}$ While acknowledging the possibility of synergistic gains, Easterbrook and Fischel suggest that they are an improbable explanation of hostile takeovers because they are likely to be realized through a friendly merger. ${ }^{26}$ But any motive for a negotiated merger might also lead a prospective acquirer to make a hostile tender offer. Incumbent management may refuse to participate in merger negotiations or may insist on terms that the prospective acquirer is not willing to accept.

Third, a firm may attempt an acquisition because it has information suggesting that the target's stock is currently undervalued. ${ }^{27}$ The recent wave of bids for oil companies, for example, may well have occurred because the prices of the companies' shares did not fully reflect the value of their oil reserves. ${ }^{28}$ To the extent that the takeover process leads the market to revise its valuation of the target, the process will be accompanied by an increase in the combined stock market value of the target and the acquirer. ${ }^{29}$ It must be emphasized,

the tax liability of the other company. For a recent example of acquisitions motivated by tax savings, see Friedman, The Truck-Leasing Triangle, N.Y. Times, Jan. 7, I982, at DI, col. 3 (tax savings resulting from combinations of insurance brokers and truck lessors).

24 Because most takeovers are of the conglomerate type, increased market power is presumably not a dominant source of synergistic gains. Still, there are some horizontal and vertical acquisitions, and even conglomerate mergers may have some anticompetitive effects. See P. STEINER, supra note $2 \mathrm{I}$, at $69-74,2 \mathrm{I} 8-87$ (problems of reciprocity and reduction in potential competition created by conglomerate mergers).

25 See, e.g., P. SteINER, supra note $2 \mathrm{I}$, at 47-95; Bradley, supra note 20 ; Gilson, supra note 8, at 873-74; Jarrel \& Bradley, supra note 14 , at 382-84; Lintner, supra note $2 \mathrm{I}$; Shay, Setting the 'Right' Premium In an Efficient Market, MERgers \& ACQUisitions, Spring I98I, at 23.

${ }^{26}$ See Easterbrook \& Fischel, supra note I, at Ii69.

27 See id. at 1160 ; Grossman \& Hart, The Allocational Role of Takeover Bids in Situations of Asymmetric Information, 36 J. Fin. 253 (I98I).

28 See, e.g., The New Urge to Merge, NewsweEk, July 27, I981, at 50, 50, 54. In a recent ruling against Mobil's bid for Marathon Oil, the Sixth Circuit reasoned:

Mobil Corporation did not convince the District Court that the merger would benefit the economy, increase operating efficiency, bring advantages of scale, or substitute better management. Mobil's reasons for the acquisition, according to the testimony of its President, Mr. Tavoulareas, and others, seem to be that Marathon stock was underpriced in the market and that Marathon's valuable Yates Field in Texas would provide Mobil with additional needed domestic crude oil reserves.

Marathan Oil Co. v. Mobil Corp., 5 Trade Reg. Rep. (CCH) (Trade Cas.) 64,420, at 75,070 (6th Cir. Dec. 23, 198I) (emphasis added).

${ }_{29}$ See Grossman \& Hart, supra note 27. A speculative motive is thus consistent 
however, that the takeover does not increase the target's true value; it only makes the market aware of an already existing value. The takeover merely accelerates an adjustment in the market price that would ultimately occur anyway. A "speculative" acquisition may produce a social benefit - it does "correct" the market price - but the benefit is smaller than the stock gains accompanying the acquisition.

Finally, the managers of the offeror may be motivated in part by the prospect of expanding the size of the enterprise under their control. ${ }^{30}$ It is widely accepted that managers prefer to increase the size of their firm because their income, perquisites, and prestige ususally increase with firm size. ${ }^{31}$ Although the expansion motive may not dominate in many or even any takeovers, it may often exist alongside other motives. Easterbrook and Fischel deny the existence of this motive and argue that the acquirer itself will be subject to a takeover if its management is not profit maximizing. ${ }^{32}$ But although the takeover threat reduces managements' divergence from profitmaximization, there is no doubt that some divergence may exist in every firm. ${ }^{33}$ The expansion motive is consistent with both the economic theory of the firm and the existing empirical evidence. ${ }^{34}$

The remainder of this Comment assumes that the dominant motives for tender offers are gains from synergy and from improved management, and that takeovers, by and large, increase social welfare. It should be kept in mind, however, that many offerors are at least partially motivated by tax savings, speculative profit, and preference for expansion -

with the evidence, see sources cited supra note 20 , that takeovers are accompanied by an increase in the combined stock market value of the target and the acquirer.

30 See, e.g., R. Marris, The Economic Theory of 'Managerial' Capitalism I22-24 (I964); Marris \& Mueller, The Corporation, Competition, and the Invisible Hand, i 8 J. EcoN. Literature 32, 4I-45 (I980).

31 See, e.g., W. Baumol, Business Behavior, Value and Growth 45-52 (rev. ed. I967); R. MARRIS, supra note 30, at 46-I09; Baumol, On the Theory of Expansion of the Firm, 52 AM. ECON. REv. I078 (1962); Marris \& Mueller, supra note 30, at $40-45$.

32 See Easterbrook \& Fischel, supra note I, at II 73.

33 See, e.g., Jensen \& Meckling, supra note $\mathrm{I} 8$, at 3 $12-\mathrm{I} 3$ (some agency costs exist whenever management and ownership do not overlap). Because the tender offer process is frictional, it cannot perfectly police incumbent managements. See also infra note $8 \mathrm{I}$ (discussing implications of friction in the tender offer process).

34 Several empirical studies find that, on average, acquirers make little or no gain, or that they even lose. See, e.g., Dodd \& Ruback, supra note 20 . At any rate, even if the evidence were conclusive that acquirers, on average, earned profits from takeovers, it would not rule out the possibility, well grounded in the economic theory of the firm, that a significant number of acquirers' managements are in part motivated by the prospect of expanding their firm. 
private benefits that do not entirely represent social gains. It also should be emphasized that takeover gains may depend substantially on the acquirer's identity. The magnitude of synergistic gains clearly depends on the "fit" between the acquirer and the target, and acquirers may well differ in their ability to improve the management of the target.

\section{The Perspective of Targets' Shareholders}

The optimal legal rule for shareholders of potential targets is one that maximizes the value of their shares. The value of a firm's stock depends on: (I) the firm's performance under its present management; and (2) the probability that a merger or a takeover will occur multiplied by the premium expected from such an event. ${ }^{35}$ This Part examines the effects of a rule of auctioneering on the factors that determine the shareholders' wealth.

\section{A. The Effect on Search by Potential Offerors}

An increase in the likelihood of a takeover benefits the shareholders of potential targets in two ways. ${ }^{36}$ First, it increases the probability that they will receive a premium. Second, strengthening the takeover threat may induce present managements to be more profit maximizing. The more that prospective offerors search, the greater is the likelihood that a potential takeover target will be identified. The amount of search that will be conducted depends on its costs and benefits.

Easterbrook and Fischel object to a rule of auctioneering because they are concerned that it will severely curtail the search for potential targets and consequently the number of offers. ${ }^{37}$ The first bidder incurs search costs to identify the target. Subsequent bidders, alerted to the target's existence by the first bidder's offer, will not bear these costs. Easterbrook and Fischel suggest that a bidding contest all but denies the first bidder any return on its search. Therefore, under a rule of auctioneering, firms have hardly any incentive to be the

35 See Easterbrook \& Fischel, supra note I, at II64. Their criterion is similar, except that it does not incorporate the probability of a merger and the premium expected in a merger.

36 Id. at I I $73-74$.

37 Id. at I $177-78$. Indeed the model they present suggests that a rule of auctioneering will eliminate search by offerors altogether. They note that their model does not accurately describe reality, but they claim that it "reveal[s] tendencies." Id. at II $73 \mathrm{n} .4 \mathrm{I}$. 
first bidder; search for targets and takeovers will be severely diminished.

Undoubtedly, bidding contests have some adverse effect on the amount of search done by prospective offerors. The following analysis suggests, however, that a rule of auctioneering is consistent with a substantial amount of search.

The prevailing rule of auctioneering does not eliminate significant returns to the search for targets. First, searchers are rewarded by the opportunity to invest profitably in the stock of targets they discover. ${ }^{38}$ A searcher that has identified a target may, and often does, start purchasing the target's shares in the market prior to making a tender offer. ${ }^{39}$ The searcher may purchase five percent of the target's stock without being required by the Williams Act to disclose the purchases. ${ }^{40}$ Whether the searcher wins or loses a subsequent bidding contest over the target, it will earn a gain on its preoffer purchases of the target's stock. ${ }^{41}$ The gain is likely to be substantial and may approach two to three percent of the target's value. ${ }^{42}$

38 See Gilson, supra note 8 , at $87 \mathrm{I}$.

39 For a recent example, see Cole, IC Offers $\$ 45$ I Million for Sunbeam, N.Y. Times, Sept. 22, 198I, at DI, col. 3 (before making an unsolicited offer for the Sunbeam Corporation, IC Industries purchased $4.5 \%$ of Sunbeam's stock).

40 As amended, $\S_{I_{3}(d)(I)}$ of the Williams Act requires any person who obtains more than five percent beneficial interest in a company to file with the SEC. I5 U.S.C. $\$ 78 \mathrm{n}(\mathrm{d})(\mathrm{I})(\mathrm{I} 976)$

${ }^{41}$ If the searcher holds $X$ shares of the target and the target is acquired through a tender offer for all shares at a premium of $\$ Y$ per share, the searcher will gain $\$ X Y$ on its pre-offer purchase, regardless of the acquirer's identity. If the acquirer is a competing bidder, the searcher will earn $\$ X Y$ by tendering the stock it holds to the winner. If the searcher itself acquires the target, it will have to pay $\$ X Y$ less than it would have paid if it were a second bidder and had not made a pre-offer purchase of the target's stock.

Even if no tender offer is successful and the target remains independent, the postoffer price of its shares is likely to exceed the pre-offer price that the searcher paid for its holdings. See Dodd \& Ruback, supra note 20, at 362-63; Jarrel \& Bradley, supra note $\mathrm{I} 4$, at $397-98$.

42 Jarrel \& Bradley, supra note $\mathrm{I} 4$, at $373,389-90$, finds that the average takeover premium between 1968 (when the Williams Act was enacted) and 1977 was $52.8 \%$ in takeovers not subject to state tender offer statutes, and $73.1 \%$ in takeovers subject to such statutes. Several other empirical studies examine the gains that targets' shareholders realize on their stock as a result of takeovers. These studies, however, use samples that include pre- 1968 takeovers, and thus presumably underrepresent the gains to targets' shareholders in the post-I 968 period, when the Williams Act facilitated competing bids. Nonetheless, even the findings of these studies suggest that the searcher can profit substantially from pre-offer purchases of the target's stock. See Bradley, supra note 20 , at $345-46$ (an average premium of $49 \%$ and average gain on nontendered shares of $36 \%$ between I 962 and I977); Dodd \& Ruback, supra note 20 , at $356-67$ (an average gain of $20.6 \%$ on target's stock in successful tender offers 
Second, a searcher may discover a target whose acquisition will bring greater synergistic or managerial gains to the searcher than to any other potential acquirers. If a searcher discovers a target with assets it values more highly than do other potential buyers, it will win any bidding contest even if the searcher has no advantage as first bidder. This contest will leave the searcher with a surplus, for it will have to pay only slightly more for the target than other bidders would be willing to pay; it need not pay as much as its own valuation of the target. ${ }^{43}$ Because acquirers may vary significantly in their valuation of a target, that surplus may be substantial.

Third, although a rule of auctioneering goes far toward placing competing potential acquirers on equal footing, it unfortunately cannot always ensure that the first bidder will have no systematic advantage. Because the period for making competing bids is necessarily limited, the first bidder will have much more time to study the target than will other potential buyers. The first bidder may thus have an informational advantage, at least over those other potential buyers to which management does not provide information about the target. ${ }^{44}$ Additionally, the initial offeror may have a strategic advantage by virtue of being the first to commit itself to a possible contest. 45

Not only does the prevailing rule of auctioneering maintain substantial rewards for search, but also the search costs that first bidders incur do not seem to be at all large. ${ }^{46}$ The search

between 1958 and I976); Kummer \& Hoffmeister, supra note 20, at 5 I I (an average gain of $18.6 \%$ to targets' shareholders between I958 and 1974).

${ }^{43}$ The possibility of such a gain is noted by Easterbrook \& Fischel, supra note I, at $\mathrm{I} I 77$ n.4I.

${ }^{44}$ While the prevailing rule of auctioneering allows management to provide information to potential competing offerors, unfortunately management may elect not to do so or to provide information to a particular "white knight" but not to other potential buyers. See infra p. I055.

45 See generally T. Schelling, The Strategy of Conflict 2 I-52 (ig6o) (discussing irreversible steps that produce strategic advantages). For example, consider a case in which both $A$, the first bidder, and $B$, another potential offeror, value the target by $\$ X$ per share, and $B$ is aware of $A$ 's valuation of the target. $A$ has already incurred the transaction costs involved in making a tender offer, and now $B$ is considering whether to make these expenditures and advance a rival bid. Because the transaction costs involved in $A$ 's bid are sunk, $A$ will be prepared to raise its bid for the target to anything less than $\$ X$ per share. Thus, to win a contest over the target, $B$ will have to bid $\$ X$ per share in addition to spending the transaction costs involved in making a bid. Consequently, $B$ 's rational decision will be not to enter into a contest with $A$, even though $B$ 's valuation of the target is the same as $A$ 's. Admittedly, the strategic advantage a first bidder may have is small, but it should be considered in light of the small size of the search costs that first bidders incur.

${ }^{46}$ See Gilson, supra note 8, at 870 . Easterbrook and Fischel fear that first bidders incur substantial search costs. See Easterbrook \& Fischel, supra note I, at II 78-79. 
for targets involves analysis of data about different companies, most of which is publicly available. Because prospective acquirers often lack appropriate in-house resources, the search is frequently done for them by investment bankers. ${ }^{47}$ When investment bankers conduct the search in addition to processing the offer, the search costs are a fraction of their total fees. Investment bankers' fees, in turn, are often less than one percent of the target's value. ${ }^{48}$ Moreover, these fees are usually contingent upon the success of the acquisition attempt; if the first bidder does not gain control over the target, it usually will have to pay the investment banker only a very small, often negligible, amount. ${ }^{49}$

The conclusion that searchers receive significant rewards relative to search costs is supported by the evidence. A large number of acquisitions do occur under the prevailing rule of auctioneering, ${ }^{50}$ a fact that reflects a substantial underlying

47 See, e.g., Feinberg, Poaching is the new name of the game, INST'L INVESTOR, Nov. I980, at $37,4 \mathrm{I}$. An investment banker's search is often undertaken at the invitation of a prospective acquirer interested in buying a company with certain characteristics. The investment banker will then study and screen companies that may fit the client's plans. Alternatively, an investment banker may, on its own initiative, identify and study a company whose acquisition may be profitable, and then look for an appropriate buyer and approach it with the acquisition idea. Easterbrook and Fischel recognize that search for targets may actually be done by investment bankers. See Easterbrook \& Fischel, supra note I, at I 78.

Some search may also be conducted for prospective acquirers by other outside professionals, such as management consulting firms. Merger brokers, who are very active in purchases of small, privately held companies, are less involved in the search for potential takeover targets (that is, publicly traded companies with clear separation between management and ownership).

48 See Carrington, Merger Advisers Say the Big Fees They're Charging Are Warranted, Wall St. J., July I7, I98I, at 29; Deals of the Year, ForTUNE, Jan. 25, I982, at 36 . Investment bankers provide several important services to a prospective acquirer throughout the tender offer process. Thus, when an investment banker's total fee includes a search component, it constitutes only a limited, and possibly minor, fraction of the total fee.

49 See Carrington, supra note 48 ; Deals of the Year, supra note 48 , at 36.

50 In I 98 I, there were I 66 acquisitions of publicly traded companies, of which 60 were by takeover. Letter from Tomislava Simic, Director of Research, W.T. Grimm Co., to Lucian Bebchuk (Jan. 25, I982) (on file in Harvard Law School Library) (data collected by firm specializing in mergers). In addition, there were 646 acquisitions of parts - divisions, subsidiaries, or product lines - of publicly traded companies (divestitures). Id. The search by prospective acquirers is reflected not only in takeovers but in acquisitions of all kinds. A prospective acquirer that has identified a company as a candidate for beneficial acquisition may well approach the company's management and negotiate acquisition of the company or of the part of the company that is particularly valuable to the prospective acquirer. See infra p. 1042. It should be noted, however, that not all acquisitions are the result of prior search by the buyer. The seller initiates a significant share of acquisitions (probably even the majority of divestitures), and these acquisitions thus reflect prior search by the seller's management for an appropriate buyer. See infra p. I046. 
level of search. ${ }^{51}$ Undoubtedly, any enhancement of the rewards to searchers will raise the investment in search: publicly available data about companies will be examined even more intensely than at present, and perhaps some new and costly methods of search will be adopted. The number of unidentified acquisition opportunities that incremental search will discover, however, presumably declines as the level of search rises. Therefore, because current search activity is substantial, it is far from clear that a given increase in the incentives for search will substantially increase the number of identified targets.

Finally, it should be emphasized that, if an increase in existing rewards for search is desirable, some enhancement may be accomplished without abandoning the rule of auctioneering. This can be done by raising the percentage of the target's stock that may be purchased without disclosure. Although the increase must be limited in order not to frustrate competing bids, ${ }^{52}$ it will still substantially raise the profits that searchers can earn on pre-offer purchases of the target's stock. From the perspective of targets' shareholders, abandonment of the rule of auctioneering to enhance further rewards for search is justified only if the resulting increase in offer frequency can be expected to be so large that it will outweigh the loss of the rule's significant positive effect on premiums.

\section{B. The Effect on Premiums in Unsolicited Takeovers}

Because Easterbrook and Fischel believe that a rule of auctioneering will severely curtail search for targets and thus unsolicited takeovers, they pay little attention to the effect of the rule on premiums in the takeovers that do occur. ${ }^{53}$ As the

51 The number of acquisitions reflects only a fraction of the potential targets that prospective offerors identify. A company will be acquired only if: (I) it is identified as one whose acquisition will produce a gain; and (2) this gain exceeds the transaction costs that will be incurred in an acquisition. Thus, when the gain that can be produced by an acquisition is below the threshold level of transaction costs, there will be no offer and no acquisition. This will occur regardless whether a rule of auctioneering is maintained or abandoned; the existence of competition is immaterial simply because no net gain can be made from an acquisition.

At present, an important source of transaction costs is management's ability to employ obstructing tactics. Thus, a prohibition of such tactics, which this Comment supports without regard to its effect on offer frequency, can be expected to increase the number of offers. The increase in offer frequency will result not from an increase in search, but rather from an expansion of the set of companies that can be profitably acquired.

${ }^{52}$ See infra p. 1054.

${ }^{53}$ See Easterbrook \& Fischel, supra note I, at I $778-80$. 
preceding Section demonstrated, however, the rule is entirely consistent with a substantial amount of search; it is therefore necessary to consider carefully the rule's effect on premiums.

Competition among potential buyers generally raises the price a seller will receive. Such competition is especially important for the sellers in a corporate takeover, however, because targets' ownership is usually dispersed. Dispersed target shareholders who face only one potential buyer, the initial offeror, are subject to a particular disadvantage that a sole owner would not suffer. If the target had a sole owner, the owner could bargain with the buyer over division of the gains from the acquisition. But the dispersed shareholders are presumably unable to organize and threaten to block the takeover, insisting on receiving some specific share of the gains. ${ }^{54}$

When each small shareholder decides whether to tender or to hold out, he will ignore the effect of his decision on the success of the tender offer in attracting the number of shares necessary for control. The shareholder will consider whether, assuming the offer is successful, he will be better off tendering his shares or holding out. Takeovers are frequently the first stage of a two-step merger and are followed by a freezeout, in which nontendering shareholders receive cash or securities for their shares. ${ }^{55}$ Given the current legal rules governing corporate freezeouts, the value of the consideration paid to nontendering shareholders, while presumably higher than the shares' pre-offer price, is unlikely to exceed, and may be lower than, the value of the tender offer. ${ }^{56}$ Indeed, some recent tender

${ }^{54}$ It is assumed here that, as this Comment recommends, management is barred from blocking tender offers. If management could block a takeover, it could, of course, threaten to do so unless shareholders receive some specific premium. Giving management bargaining power by allowing it to block a takeover is not, however, an acceptable solution to the problem of shareholders' inability to organize and bargain with the offeror as a sole owner would. Management may well use its power not to bargain for a higher premium, but rather either to avoid a takeover altogether or to extract personal benefits from the offeror in return for abstaining from blocking.

${ }^{55}$ See, e.g., Dodd \& Ruback, supra note 20, at 352.

${ }^{56}$ In a freezeout, the acquirer is constrained by the appraisal rights of the nontendering shareholders. Appraisal statutes, however, generally exclude from the required compensation any element of value arising from the expectation or accomplishment of a merger. See, e.g., Del. Code ANN. tit. 8, \$262(f) (Supp. 1980); N.Y. Bus. CoRP. LAW $\S 623(\mathrm{~h})(4)$ (McKinney I 963 ). The appraisal process may thus ensure that nontendering shareholders receive the value of their shares in the independent target, but it is not designed to give them any share of the gains from the target's acquisition. See Brudney \& Chirelstein, Fair Shares in Corporate Mergers and Takeovers, 88 HARV. L. REv. 297, 304-06, 336-37 (1974).

Professors Brudney and Chirelstein propose the imposition of a fairness requirement that the acquirer pay the same price per share on freezeout as it offered on tender. Id. at $337-40$. This requirement would significantly reduce the pressure on 
offers have been accompanied by the offeror's announcement that it contemplated a freezeout in which nontendering shareholders would receive securities with a significantly lower value than that of the initial offer. ${ }^{57}$ The threat of a subsequent freezeout may thus pressure shareholders to tender their shares for the premium offered, ${ }^{58}$ even if the premium is one they would likely reject were they able to organize. ${ }^{59}$

The existence of large shareholders, who take into account the effect of their decisions on the success of the tender offer, may strengthen the bargaining position of the target's shareholders. But as long as the majority of the target's stock is owned by small shareholders with insignificant holdings, a potential buyer that does not face competition may well acquire the target for a low premium constituting only a small fraction of the takeover's gains. Only a competing offer, or the threat of such an offer, will enable the dispersed target's shareholders to get a substantial share of those gains. ${ }^{60}$

the target's shareholders to tender. But it has not been adopted by the courts. See, e.g., Tanzer v. International Gen. Indus., 402 A.2d 382, 393-95 (Del. Ch. I979). At any rate, even if the rule were adopted, the pressure to tender, albeit much weaker, would still exist. If the tender offer is successful and a freezeout follows, holding out will result in receiving the tender price, but at a later point in time.

${ }^{57}$ For example, in the recent takeover of Marathon Oil by U.S. Steel, U.S. Steel offered $\$ 125$ in cash for tendered shares and announced that it was contemplating a subsequent freezeout in which nontendered shares would be converted into the right to receive $\$ 100$ of U.S. Steel notes. See N.Y. Times, Dec. 2, I98I, at D4, cols. I-3 (notice of supplement of U.S. Steel's offer). The premium in that takeover was sizable, nonetheless, because Mobil had also made a bid and additional potential buyers were waiting in the wings.

58 Pressure to tender is likely to exist even if the offeror is not expected to arrange a freezeout following the offer's execution. Although nontendering stockholders will be able to retain their shares in such a case, the value of those shares after the offer's execution is likely to be lower than the value of the tender offer. This will certainly be true of the shares' value in the acquirer's eyes, if the acquirer will not arrange a freezeout. The reason why an acquirer may value nontendered shares at less than the price it will have to pay for them in a freezeout is presumably that control over the target enables the acquirer to siphon directly to itself part of the takeover's gains.

${ }^{59}$ Gilson, supra note 8, at 859-62, examines the pressure on shareholders to tender and suggests that it is unlikely to result in acceptance of offers that will make the shareholders worse off than they were before the offer. I agree with Professor Gilson. The freezeout threat is unlikely to lead shareholders to accept such offers because the price in a freezeout presumably will be at least as high as the shares' pre-offer price. The argument made here, however, is that shareholders might be pressured into accepting offers that, though making them better off, provide them with only a small fraction of the takeover's gains.

${ }^{60} \mathrm{It}$ is possible to argue that the existence of some pressure on shareholders to tender is essential for the takeover process to function. As explained above, each small shareholder, when making his tender decision, compares (I) the expected price of nontendered shares immediately following the offer's execution (assuming the offer will be successful), with (2) the offer's value. If (I) is lower than (2), shareholders will 
Even if the target's shareholders did not have the bargaining disadvantage of dispersed ownership - if they were in the position of a sole owner - a rule of auctioneering would still increase premiums substantially. First, in the absence of any buyers other than the initial offeror, the distribution of any part of the takeover's gains is subject to bargaining between the offeror and the seller. A rule of auctioneering will compel the initial offeror to pay at least the premium that other potential buyers are willing to pay. Moreover, the initial offeror may not be the firm that attaches the highest value to the target's assets. In that case a rule of auctioneering will lead to a takeover by a firm that values the target more highly and can thus pay a higher premium.

It should be pointed out that the beneficial impact of a rule of auctionering on premiums is not limited to those instances in which competing bids are actually made. Under the prevailing rule of auctioneering, many unsolicited offers are not challenged by competing bids. ${ }^{61}$ The premiums in such cases are still affected by the rule, however, because they are augmented by the first bidders to eliminate or reduce the threat of competing offers. If that threat did not exist, the bidders would offer much smaller premiums. Thus, a rule of auctioneering significantly raises the premiums in all unsolicited takeovers.

\section{The Effect on Negotiated Acquisitions}

Not all acquisitions are the result of unsolicited tender offers. An acquisition may also be the product of negotiations

be pressured to tender, even if that is not in their collective self-interest. On the other hand, if (I) exceeds (2), shareholders will be induced to hold out, even if acceptance of the offer is in their collective self-interest. (And if (I) and (2) are equal, many shareholders who ignore the effect of their decision on the offer's success will still not bother to tender). Thus, the argument goes, takeovers of companies with dispersed ownership will not be possible, no matter how generous the offers are, unless offerors can treat nontendering shareholders less favorably than tendering ones. $C f$. Grossman \& Hart, Takeover bids, the free-rider problem, and the theory of the corporation, I I BELL J. ECON. 42 (I980) (dilution of the rights of nontendering shareholders is essential for the takeover process to function).

This Comment does not address the question whether pressure on shareholders to tender is essential for takeovers. The analysis merely demonstrates the existence of pressure to tender under the current state of the law and consequently concludes that, at present, competition among acquirers is crucial if a target's shareholders are to receive a significant share of the takeover's gains. If such pressure is indeed essential for takeovers, the above conclusion will simply become one of greater generality.

61 See, e.g., Austin, Tender Offer Update: 1978-1979, Mergers \& Acquisitions, Summer I980, at I3, I7; Bradley, supra note 20; Dodd \& Ruback, supra note 20; Kummer \& Hoffmeister, supra note 20. 
between the target's management and the acquirer. After identifying a target, a prospective acquirer may well approach its management with an offer of acquisition. ${ }^{62}$ The initiative for acquisition negotiations may also come from the target's management. Once the management and the prospective acquirer agree on terms, a negotiated acquisition will be consummated by a merger ${ }^{63}$ or a friendly takeover. ${ }^{64}$

At present, most acquisitions are negotiated and not the result of unfriendly takeovers. ${ }^{65}$ To determine whether a rule governing takeovers is desirable from the perspective of tar-

62 A negotiated acquisition may have some advantages over an unfriendly takeover, even if the target's management cannot obstruct the latter. First, in the acquisition negotiations the prospective acquirer is likely to receive from the management some nonpublic information about the target. This information would reduce the prospective acquirer's uncertainty about the gains the considered acquisition may produce, and thus would enable it better to judge whether the acquisition is profitable. See J. FreUnd, ANATOMY OF A MERger: 230-4I, 248-80 (I975); Gilson, supra note 8, at $850-5 \mathrm{I}$. Second, because a negotiated acquisition may be consummated not only through a friendly takeover but also through a statutory merger, a consolidation, or a sale of the target's assets, it may be better designed to maximize tax savings. See generally B. Bittker \& J. Eustice, Federal income TaXation of Corporations AND Shareholders If I4.0I to .57 (4th ed. 1979) (discussing tax-exempt corporate reorganizations).

Management's present ability to employ obstructing tactics provides another reason why a prospective acquirer may try to negotiate with the management rather than initiate an unfriendly tender offer. The prospective acquirer may fear that management will obstruct an unsolicited takeover bid, and may therefore seek management's approval of its acquisition. Indeed, the prospective acquirer may also try to ensure, by promising some personal benefits to the management, that the management will obstruct any tender offer initiated by other potential buyers. Thus, adopting the recommended prohibition of obstructing tactics will reduce the proportion of negotiated acquisitions, although it will not eliminate them.

${ }^{63}$ Merger refers here to all forms of acquisition, including consolidation and sale of substantially all assets, that require board and shareholder approval.

${ }^{64}$ Because the consummation of a friendly takeover requires much less time than does a merger, the former method of acquisition is usually adopted when the parties are interested in a speedy consummation. There may be a legitimate business reason for a quick resolution. But the motive behind the choice of a speedy technique may also be an improper one. See infra notes $70-7 \mathrm{I}$.

65 See Freund \& Greene, Substance over Form S-I4: A Proposal to Reform SEC Regulation of Negotiated Acquisitions, 36 Bus. LaW. I483, I485-86 (I98I). A substantial share of acquisitions are through mergers. See supra note 50. And even among takeovers a significant fraction is not hostile. See Bradley, supra note 20 , at 347; Kummer \& Hoffmeister, supra note 20, at 505.

As explained above, see supra note 62, adopting a prohibition against obstructing tactics will increase the proportion of unfriendly takeovers over negotiated acquisitions. However, this Section studies negotiated acquisitions in order to establish that the rule of auctioneering increases premiums in all acquisitions. This point will not be undermined, of course, if negotiated acquisitions are replaced by unfriendly takeovers; the preceding Section has already demonstrated that the rule significantly increases premiums in such takeovers. 
gets' shareholders, it is therefore essential to take into account the rule's effect on negotiated acquisitions. The following analysis demonstrates that the prevailing rule of auctioneering increases the premiums not only in unsolicited takeovers, but in all acquisitions as well.

It should be noted first that, if the rule of auctioneering is abandoned, many negotiated acquisitions, especially those initiated by the buyer, will be replaced by unsolicited takeovers; more importantly, these will be low-premium takeovers. A prospective acquirer that has identified a target will be induced to make a low-premium tender offer immediately. ${ }^{66}$ If the offeror approaches the management, management may start negotiating with other potential buyers. An immediate bid, however, will free the offeror from the threat of competing offers. In the absence of competition, the offeror will be able to acquire the target for a small premium. ${ }^{67}$

The premiums in negotiated acquisitions that will occur even if the rule of auctioneering is abandoned will be substantially lower than they would have been under the rule. The premiums in negotiated acquisitions are affected by the rule of auctioneering because they are determined against the background of a possible unfriendly tender offer by the acquirer or by a competing potential buyer. The rule's effect on the premium in a negotiated acquisition depends on the extent to which management abuses its role as a bargaining agent for the shareholders. To examine the rule's effect, therefore, this Section considers two polar cases. In one, management is concerned solely with maximizing the benefits the acquisition will confer on the shareholders. In the other, management is not at all concerned with the shareholders' premium and pursues only its own, different interests. Management may be at least partly concerned with the shareholders' premium because it may have incentives to increase the firm's value; 68 although

66 See Gilson, supra note 8 , at 875 .

67 If the rule of auctioneering is abandoned, low-premium unfriendly takeovers will be more likely to occur even when the target's management initiates acquisition negotiations. A prospective acquirer that has been approached by management and recognizes the potential for beneficial acquisition will be induced to launch an unfriendly bid immediately. To be sure, management may have simultaneously approached other potential buyers. But if the prospective acquirer acts quickly and if sufficient time for making competing bids is not provided, the prospective acquirer may be relatively free from the threat of competition.

68 Managers may receive part of their compensation in the firm's securities and may have thus accumulated a significant amount of such securities. Additionally, the managers' performance may affect their future job prospects. See Easterbrook \& Fischel, supra note I, at I I72; Fama, Agency Problems and the Theory of the Firm, 88 J. PoL. ECON. 288 (I 980 ). 
such an increase is rarely management's sole objective, it may well be one objective.

Consider first the case in which management is fully dedicated to the shareholders' interests. A rule of auctioneering enhances the ability of the management to advance these interests in the acquisition negotiations. The premium in a negotiated acquisition is the result of bargaining between the target's management and the acquirer, and thus depends on the parties' bargaining positions. If competing bids are impeded, the acquirer's bargaining postion will be significantly strengthened relative to that of the management. The acquirer will never be willing to pay more than it would have to spend to gain control of the target in an unfriendly takeover in which management actively seeks competing bids, and a rule of auctioneering substantially raises this ceiling.

A rule of auctioneering also increases the premium in the case in which management completely disregards the shareholders' interests. In this case management will not bargain with the acquirer for a higher premium. Instead, it will extract personal benefits in return for approving a premium smaller than other potential buyers would be willing to pay. The shareholders may be quite vulnerable to such abuse. ${ }^{69}$ It is very difficult to prove that management's judgment has been skewed by self-interest, and the need for shareholder ratification may be an inadequate protection against a tainted merger agreement. The tainted acquisition, however, is subject to the threat that another potential buyer will initiate a tender offer before the acquisition is consummated.

A rule of auctioneering, coupled with a prohibition of obstructing tactics, would enhance this threat and enable it to serve as an important check on the self-serving management and its partner. The prohibition will prevent disloyal management from obstructing tender offers that other potential buyers may initiate. The rule of auctioneering, in turn, ensures that the tainted acquisition cannot be consummated before other potential buyers have had time to initiate tender offers. Even if potential competing buyers face no obstructions, they do need time to study the target's acquisition, especially because they will receive no information from the target's management. Because consummation of a merger usually requires at least two months, ${ }^{70}$ disloyal management and

69 See, e.g., Brudney \& Chirelstein, supra note 56, at $340-44$ (discussing acquisitions tainted by side payments to management, and shareholders' vulnerability to such abuse).

70 See Freund \& Greene, supra note 65, at $1499-500$. The consummation of a merger requires substantial time because shareholders' approval is needed. It is 
its partner may choose the route of a friendly takeover in order to speed consummation of the acquisition. ${ }^{71}$ The rule of auctioneering ensures that, even in this scenario, time will be available for tender offers by other potential buyers. The smallest premium that shareholders might receive, in the presence of totally disloyal management, is the minimum premium necessary to gain control over the target in a friendly takeover; the rule of auctioneering and the prohibition of obstructing tactics substantially raise this floor.

In sum, a rule of auctioneering increases premiums in all acquisitions, unfriendly or negotiated, through merger or takeover, whether management is loyal or self-serving. By ensuring that no acquisition can occur before potential competing buyers have time to advance rival tender offers, the rule increases premiums in all acquisitions. By allowing management to solicit competing offers, the rule further raises premiums in some, although not all, acquisitions. Premiums are raised in unfriendly takeovers in which management actually seeks competing offers, and in negotiated acquisitions in which management uses the threat of soliciting bids, at least in part, to bargain for increased premiums. Management's power to solicit competing bids does not, of course, raise premiums in those negotiated acquisitions in which management refrains from solicitation solely in return for personal benefits from the acquirer. In no case, however, can the existence of this power reduce the shareholders' premium. The concluding Part of this Comment verifies this proposition.

Finally, it is important to point out that, while the positive effect of a rule of auctioneering on premiums reduces the

necessary to prepare bulky proxy statements, to file them with the SEC, to wait for and respond to the comments of the SEC's staff, and then to solicit the shareholders' votes. In most cases, materials cannot be mailed to stockholders until one month after filing with the SEC, and another month is usually required for the solicitation of votes.

Until shareholders' approval of the merger is obtained, competing potential acquirers can enter the picture. The press release concerning the merger agreement will alert competitors, which will start studying the target. If the management receives a merger offer with a higher premium, existence of the offer must be highlighted in the merger proxy statement; the chances of gaining shareholders' ratification will therefore decline. Moreover, the competing potential buyer may well initiate a tender offer and succeed in purchasing, before the shareholders' vote, enough shares to gain control over the target or at least to defeat the merger proposal.

71 See Freund \& Easton, The Three-Piece Suitor: An Alternative Approach to Negotiated Corporate Acquisitions, 34 Bus. LAw. 1679 (1979); Freund \& Greene, supra note 65 . These authors explain that the technique of friendly takeover is adopted in negotiated acquisitions mainly as a means of reducing the threat of potential competing buyers. 
incentives for search by prospective acquirers, it encourages search by targets' management. If acquisition of a company can produce gains, management may look for an appropriate acquirer. One reason why management may do so is that it has incentives to increase the firm's value. As a result of these incentives, an acquisition with a substantial premium may be in management's interest. ${ }^{72}$ Because a rule of auctioneering raises the premiums expected in an acquisition of the target, it increases the incentive for management to look for such an opportunity.

\section{The Perspective of Social Welfare}

Part II emphasized that a rule of auctioneering benefits targets' shareholders by increasing premiums. As Easterbrook and Fischel note, however, an increase in the premiums paid to targets' shareholders produces no net social gain; the increase is exactly offset by a loss to the acquirers' shareholders. ${ }^{73}$ This Part therefore inquires whether a rule of auctioneering can be opposed from the perspective of social welfare. From that point of view, the desirable legal rule is one that maximizes aggregate social welfare, regardless where the gains and losses fall. ${ }^{74}$

\section{A. The Effect on Search by Potential Offerors}

Again, the only possible objection to a rule of auctioneering is that it reduces the number of acquisitions by decreasing incentives for search. The previous Part already questioned the magnitude of that reduction in the number of acquisitions.

72 Target management's search for an appropriate acquirer may also be motivated by the expectation of receiving from the acquirer some personal benefits for management's cooperation. Thus, the recommended prohibition of obstructing tactics, which will eliminate management's ability to extract personal benefits from the acquirer in return for refraining from obstructing, will reduce management's incentive to search. Nonetheless, because obstructing tactics may be very harmful to the shareholders, the prohibition is on the whole clearly desirable. The encouragement of search by targets' managements - or by prospective acquirers - should not be pursued by all possible means. The attractiveness of a rule of auctioneering from the perspective of targets' shareholders is that it encourages search by targets' management in addition to substantially increasing premiums.

73 See Easterbrook \& Fischel, supra note I, at I 75.

74 The welfare criterion used here is the Kaldor-Hicks (Potential Pareto-Superiority) criterion, according to which a change from rule $B$ to rule $A$ is desirable if the individuals who benefit from the change could hypothetically compensate the losers out of their gains. See generally Symposium on Efficiency as a Legal Concern, 8 Hofstra L. REV. 485 (I980) (articles on the application of the Kaldor-Hicks criterion to legal rules). 
It assumed, however, that any increase in search is desirable from the perspective of targets' shareholders, even if the resulting increase in offer-frequency is quite limited. But that is not necessarily the case from society's point of view.

The search for targets has the direct social benefit of yielding acquisitions that produce social gains. It also benefits society indirectly by inducing incumbent managements to be more profit maximizing. Therefore, there is no doubt that some amount of search is socially desirable. It is also clear, however, that search should not increase without limit. Search is costly, and its marginal benefit presumably declines as its level increases. Increments in search are socially desirable only up to the point at which the marginal social cost and benefit of extra search are equal. To induce the socially optimal level of search, the private incentives for searchers must equal, at the margin, the social benefits from their activity.

Consider the incentives for search in a situation in which premiums are negligible, so that all the stock market gains produced by a takeover are realized by the searcher-acquirer. On the one hand, the private rewards for extra search exceed its direct social benefit. First, the stock market gains produced by takeovers do not entirely represent social gains created by these takeovers. A takeover may be motivated by a prior undervaluation of the target, in which case the increase in stock value simply reflects a revision in the market's estimate of the target's true value. ${ }^{75}$ The increase in stock value may also result from tax savings or from enhanced market power, ${ }^{76}$ and thus come at the expense of tax revenues or consumers. Second, acquirers' managers may be induced to search by their preference for expansion, in addition to being motivated by the prospect of gains for their firms. ${ }^{77}$ On the other hand, searchers do not capture the indirect social benefit from a marginal dollar spent on search - that is, the extent to which this extra search, by strengthening the takeover threat, will increase incumbents' devotion to shareholders' interests. In sum, the marginal private rewards for search may, or may not, exceed the marginal social benefit from it.

Hence, if competing bids are impeded, with the low premiums that result, it is possible that there will be socially excessive investment in search. To determine the desirable level of incentives for search, it is necessary to have more information than is presently available about its marginal so-

\footnotetext{
75 See supra pp. I032-33.

76 See supra notes $23^{-24}$.

77 See supra p. 1033.
} 
cial benefits and private rewards. Until such understanding is acquired, it should not be presumed that an abandonment of the rule of auctioneering will move society closer to the optimal level of search, or even that there is underinvestment in search at present.

\section{B. Other Welfare Effects}

Even if the reduction in search caused by a rule of auctioneering is undesirable, the case for the rule remains strong. While the rule's upward effect on premiums is socially neutral, the rule does have substantial socially beneficial effects.

First, acquirers may vary substantially in the amount of synergistic or managerial gains they can produce, and a rule of auctioneering increases the likelihood that the target will be acquired by the firm to which its assets are most valuable. ${ }^{78}$ When the initial offeror cannot put the target's assets to the best possible use, the rule facilitates an acquisition by a firm that values the target more highly. Additionally, the rule increases the likelihood that the initial offeror will be the most efficient user of the target's assets. ${ }^{79}$

Although Easterbrook and Fischel note that bidding contests allocate targets' assets to their most valuable uses, they attach no weight to this consideration. They suggest that, if the acquirer cannot put the target's assets to the best possible use, the assets can be resold and will eventually end up in the possession of the firm that values them most highly. ${ }^{80}$ Easterbrook and Fischel, however, ignore the fact that transfer of the assets from the acquirer to that firm may involve substantial delay, incur significant transaction costs, or even never occur. ${ }^{81}$ The transfer of corporate assets is an imperfect and

\footnotetext{
78 See Gilson, supra note 8, at 872-74.

${ }^{79}$ An investment banker may identify and study a target on its own initiative in order to approach a potential buyer later with the acquisition idea. A rule of auctioneering reduces the likelihood that any potential buyer other than the one that values the target most highly will be able to acquire the target. Therefore, because investment bankers usually receive a fee contingent on the success of the acquisition attempt, the rule greatly increases the investment banker's incentive to look for the potential buyer to which the target's assets are most valuable.

Alternatively, the target may be identified by a potential buyer (or an investment banker searching on its behalf). The finder will first purchase in the market some amount of the target's stock, which is bound to appreciate if the target will be subject to a premium takeover. Then, if the finder is clearly not the potential buyer that values the target most highly, the rule of auctioneering may induce it not to make an acquisition attempt that is likely to fail, but instead to pass the information about the target to other potential acquirers.

${ }^{80}$ See Easterbrook \& Fischel, supra note 1 , at I 76 n.40.

81 The managers of the acquirer, $A$, may prefer to retain the target's assets and
} 
frictional process; indeed, the imperfection and friction, and the desire to reduce them, are a main concern of both Easterbrook's and Fischel's article and this Comment.

Second, a rule of auctioneering encourages socially desirable investment in potential targets. Easterbrook and Fischel urge us to adopt an ex ante perspective and realize that the gains from takeovers are a consequence of prior search for targets and that incentives for search are thus desirable. ${ }^{82}$ Take the ex ante perspective one step back and one finds that the potential gains from a target's acquisition would not exist, waiting to be discovered by prospective acquirers, if not for individuals' prior decisions to establish and invest in the target. Therefore, the gains from the acquisition can also be attributed to these investment decisions, and not only to the search for targets. The same logic suggests that to induce an optimal level of investment in potential targets requires that targets' shareholders receive the social gains resulting from their investment. By providing targets' shareholders with a larger share of the gains produced when their companies are acquired, a rule of auctioneering moves society closer to the desirable level of investment in potential targets. ${ }^{83}$

Third, a rule of auctioneering encourages managements of potential targets to look for an appropriate acquirer ${ }^{84}$ Because search by managements of potential targets is presumably not motivated by speculation regarding the target's value or by preference for expansion, an increase in such search is likely to be socially desirable.

Finally, a rule of auctioneering improves the information

not sell them to firm $B$, which places the greatest value on those assets, to avoid reducing the size of the enterprise under their control. See sources cited supra note 3r. Easterbrook and Fischel argue that, if $A$ will not sell the target's assets to $B, A$ itself will be subject to a takeover by $B$. See Easterbrook \& Fischel, supra note I, at II 76 n.40. But because takeovers are costly, not every company holding some assets that are valued more highly by another firm will be taken over. Note that to acquire only the target's assets through a takeover, $B$ (which may be smaller than $A$ ) will have to acquire $A$ in its entirety (an acquisition that may create antitrust problems), and then divest itself of the "original" $A$. At any rate, a series of takeovers is a very inefficient substitute for a bidding contest that will enable $B$, the firm to which the target's assets are most valuable, to acquire those assets in a relatively prompt and inexpensive way.

82 See Easterbrook \& Fischel, supra note I, at I I $77-78$.

83 To the extent that an acquirer is "unique" in that it can produce greater synergistic or managerial gains than others, the acquirer's shareholders should be rewarded with the social gains resulting from the acquirer's existence. A bidding contest is compatible with that goal. The contest does not require the acquirer to pay as much as its own valuation of the target, but rather only slightly more than the target's value to other potential acquirers. Thus, the acquirer captures the gains from the acquisition that other potential buyers cannot produce.

${ }^{84}$ See supra pp. 1045-46 \& note 72 . 
that constitutes the basis for acquisition decisions, and thus reduces the likelihood of an acquisition that produces no gain, or even a loss. Under a rule of auctioneering, a prospective acquirer may well approach a company's management, initiate acquisition negotiations, and request specific information about the company. When management cooperates, a socially useful transfer of information follows. The prospective acquirer is likely to receive nonpublic information that it could not otherwise obtain and that will make it better able to judge whether an acquisition will be beneficial. ${ }^{85}$ If the rule of auctioneering is abandoned, however, a prospective acquirer that has identified what seems to be a promising target will be induced to launch an immediate unsolicited bid. ${ }^{86}$ An attempt to verify through target management that potential gains exist will create the danger, which an immediate bid will eliminate, that the management will start looking for other potential buyers.

\section{CONCLUSION AND IMPLiCATIONS}

Although Easterbrook's and Fischel's article contributes to the analysis of the rules governing takeovers, ${ }^{87}$ their thesis that it is undesirable to facilitate competing bids is unpersuasive. This Comment demonstrates that a rule of auctioneering has significant benefits. The rule benefits targets' shareholders by substantially raising the premium they can expect if their company is acquired, whether through a merger or through a takeover. The rule increases social welfare by enhancing in a number of ways the efficiency with which society's resources are used.

This Comment also addresses the concern that the rule has a grave impact on the search for targets. Under the prevailing rule of auctioneering, significant incentives for search are maintained, and consequently a substantial amount of search is conducted. Even if it is desirable to enhance the incentives for search, some enhancement can be accomplished without abandoning the rule. Although abandonment of the rule of auctioneering would further encourage search, the increase in search may be socially undesirable. And in any event, it is

85 See J. FREUnd, supra note 62, at 230-4I, 248-80; Gilson, supra note 8, at $850-51$

${ }^{86}$ See supra p. 1043.

87 In particular, Easterbrook and Fischel demonstrate that the rationale behind the business judgment rule is inapplicable to management's resistance to takeovers, and refute arguments that may be made for allowing management to employ obstructing tactics. See Easterbrook \& Fischel, supra note I, at I I82-99. 
far from clear that the resulting increase in the number of acquisitions will be substantial.

Admittedly, no conclusive proof can be offered that the positive effects of a rule of auctioneering outweigh its possibly adverse effect on the search for targets. But the analysis does suggest that the rule is desirable from the perspectives of both targets' shareholders and social welfare. The legal system should therefore continue to facilitate competing tender offers.

Before examining the implications of this conclusion, a qualification should be emphasized. Although the facilitation of competing bids significantly serves the interests of society and targets' shareholders, it is not sufficient to protect those interests fully. The concerns created by the dispersed ownership of targets are only mitigated and not eliminated by the existence of competition among acquirers.

One source of concern is that shareholders may lack adequate information to evaluate tender offers. Incapable of concerted action, shareholders are unable to demand from an offeror information that a sole owner would insist on. ${ }^{88} \mathrm{An}$ other source of concern is that shareholders' tender decisions may deviate from what is in their collective self-interest. To be sure, a rule of auctioneering does improve the terms of the tender offers that targets' shareholders face. Nonetheless, while a rational sole owner may at times choose not to accept, at least temporarily, the offers made to him, this course of action might be much more difficult for a target's dispersed shareholders. ${ }^{89}$ Examination of these problems and whatever legal intervention they require, however, is beyond the scope of this Comment.

\section{A. The Regulation of Offerors}

The regulation of offerors should be designed to facilitate competing tender offers, and present regulation generally goes in the right direction. 90 Primarily, the regulation of offerors

88 This problem may be addressed by regulation requiring an offeror to provide target shareholders with the information that a sole owner would be likely to demand. It is not possible to examine here whether current disclosure requirements are appropriate in light of this criterion. See I7 C.F.R. \$240.14d-6 (I98I) (disclosure requirements prescribed by the SEC).

89 Allowing incumbent management to block tender offers is clearly not the way to address this problem. See supra note 54 .

90 Tender offers are at present regulated by both the Williams Act, I5 U.S.C. $\S \S 78 l(\mathrm{i}), 78 \mathrm{~m}(\mathrm{~d})-(\mathrm{e}), 78 \mathrm{n}(\mathrm{d})-(\mathrm{f})(\mathrm{I} 976)$, and state tender offer statutes. This Comment does not address questions of the state statutes' constitutionality and the desirability of two sets of regulations. See State Takeover Statutes and the Williams Act, 32 Bus. LAW. I87 (1976); Note, Securities Law and the Constitution: State Tender Offer 
should provide the time necessary for realizing the potential benefits from competition among acquirers. Even when management provides potential buyers with information about the target, potential buyers need time to verify and assess that information and to decide if they should make a competing offer. They need even more time if they do not receive management's cooperation, which may possibly be denied because the initial offeror promised management some personal benefits. And if alternative offers are made, shareholders need time to evaluate them.

Given that time is essential, it is still necessary to explain why it has to be provided by regulatory intervention. One could argue that the offeror and the target's shareholders should be free to consummate a transaction as quickly as they wish. If the acquirer asks for an acceptance within a very short period and the shareholders believe a better offer may be forthcoming, so the argument goes, they may simply hold out.

As explained, however, the dispersed shareholders of a target might find it difficult to refuse an offer even if refusal is in their collective self-interest. If the shareholders could cooperate, they presumably would often agree among themselves to wait for some limited period and explore the possibility of a better offer. Because transaction costs make such an agreement impossible, delay should be secured by regulation preventing shareholders from committing themselves to an acquirer during a cooling-off period. This period can be provided by allowing shareholders to withdraw tendered shares for some specified time after an offer is made. ${ }^{91}$ It is also possible to extend the period by requiring that an offer be published some prescribed time before its effective date. ${ }^{92}$

Statutes Reconsidered, 88 YALE L.J. 5 IO (I979). The concern here is with the desirable substantive content of the regulation of offerors.

91 See 15 U.S.C. $\$ 78 \mathrm{n}(\mathrm{d})(5)$ (1976) (tendered shares can be withdrawn within seven days after an offer is made); I7 C.F.R. $\$ 240.14 d-7$ (a)(I) (I98I) (SEC rule extending the withdrawal period to I5 business days). A number of state tender offer statutes prescribe longer withdrawal periods. See E. ARANOw, H. EINHORN \& G. Berlstein, Developments in Tender Offers for Corporate Control $240-42$ (I977).

92 The proposed Federal Securities Code drafted by the American Law Institute requires offerors to publish a "definitive notice" of the tender offer at least to days before the tender offer is made. FED. SEC. CODE $\$ 606$ (d)(2) (Proposed Official Draft 1978). Almost all state tender offer statutes require that the offeror file information concerning the offer with the state securities commissioner, or at least furnish it to the target company, some given time (usually varying between Io and 30 days) before making the offer. See E. Aranow, H. Einhorn \& G. Berlstein, supra note 9I, at 2 I2. The problem with the waiting periods produced by the state filing and 
How long a delay should regulations prescribe? The danger from mandating too short a period is clear. In many cases, time pressure would impede competing offers, and an additional delay would therefore secure a higher price for shareholders and possibly a more valuable use of the target's assets. On the other hand, lengthening the delay period imposes costs. A quick resolution of the target's fate will enable all parties involved to know where they stand, and to plan their future actions, at an earlier time. The acquirer, for one, will be able to implement promptly its plans for the use of the target's assets. In addition, offerors that keep their offers open bear the costs of the uncertainty of changing circumstances.

Adoption of the recommended ban on obstructing tactics will provide a basis for lengthening the delay period. First, the ban will alleviate the concern that a longer delay will give management more time to construct obstructions. Second, the ban will prevent dedicated management from gaining an extension in order to secure a competing offer, which in turn will make a longer regulatory delay desirable. The appropriateness of the current delay period should be reconsidered in light of all the considerations discussed above. While this Comment does not recommend a specific figure, the fifteenbusiness-day period prescribed by the present federal regulation ${ }^{93}$ does seem more likely to be insufficient than excessive. ${ }^{94}$

In addition to the standard delay period prescribed for all offers, an effort should be made to identify particular circumstances in which an extension is warranted. One such case arises when a competing bid is made very close to the end of the standard delay period. Because shareholders will need time to compare the alternative offers, it is desirable to mandate a short additional delay. ${ }^{95}$

notification requirements is that the disclosure of the offer is not made to the public. Thus, trading in the target's stock may continue with little or no information being supplied to the market. See Freund \& Greene, supra note 65, at 1497-98; State Takeover Statutes and the Williams Act, supra note 90, at 196-97. Moreover, the facilitation of competing bids will be served by a public disclosure, so that all potential competing buyers will be alerted even if the target's management does not contact them.

${ }_{93}$ See supra note $9 \mathrm{r}$.

94 The proposed Federal Securities Code extends the present delay period. It prescribes a ro-day advance publication of the offer. FED. SEC. CODE $\S 606(d)(2)$ (Proposed Official Draft 1978). Additionally, it requires offers to be open for at least 20 days, id. $\$ 606(\mathrm{e})$, and allows shareholders to withdraw tendered shares at any time until two days before expiration of the offer, id. $\S 606(\mathrm{~h})$.

95 See I7 C.F.R. $\$ 240.14 \mathrm{~d}-7(\mathrm{a})(2)$ (I98I) (SEC rule allowing withdrawal of tendered shares within io business days after another bidder makes a tender offer for the same class of securities). 
Finally, to facilitate competition among acquirers, it is necessary to limit the amount of the target's stock that a prospective acquirer may purchase secretly. 96 As explained above, allowing prospective offerors to make an undisclosed purchase of some amount of stock is instrumental in inducing search for targets. That amount of stock must be quite limited, however, lest the searcher lock up the target for itself or at least erect significant obstacles against competitors. A prospective acquirer that has purchased the specified amount of the target's stock should disclose its acquisition intentions and thus enable other potential buyers to make their own offers to the shareholders within the prescribed delay period.

\section{B. The Role of Incumbent Management}

Although the possibility that resistance by management will facilitate competing bids is not a ground for concern - quite the contrary - there is a strong basis for opposition to obstructing tactics. Management cannot be trusted to use these tactics primarily to gain a limited delay that will facilitate a bidding contest. First, it may employ these tactics to avoid a takeover altogether and perpetuate its control. Alternatively, it may use them to distort an existing contest among prospective acquirers: it may obstruct other contenders in order to favor one that offers a better deal for management but worse terms for the shareholders. Therefore, time for making competing bids should be provided solely by regulatory mandate, and incumbent management should be barred from actions that obstruct any tender offer.

While management should not obstruct existing offers, this Comment recommends that it be assigned the auctioneering role of expanding the set of offers shareholders face. Management should be allowed to look, on its own or through investment bankers, for other potential buyers and to provide them with information about the target that will facilitate their decisions to make competing bids. Indeed, management should be required, as part of its fiduciary duty, diligently to seek a higher offer if achieving such an offer appears feasible.

Once a regulatory delay is prescribed, why is management's auctioneering ever necessary? Potential acquirers may have difficulties in gathering, within the limited delay period, all

\footnotetext{
96 See 15 U.S.C. $\$ 78 \mathrm{n}(\mathrm{d})(\mathrm{I})$ ( 1976 ) (requiring disclosure of an acquisition of more than $5 \%$ of a company's stock). The original disclosure threshold was 10\% ownership, see Williams Act, Pub. L. No. 90-439, § 2, 82 Stat. 454, 455-56 (1968); the 5\% threshold was established in 1970, see Act of Dec. 22, I970, Pub. L. No. 91-567, § 3, 84 Stat. I497, I497.
} 
the information necessary for deciding whether to make a competing bid, and management can provide them with that information. The extent to which management's solicitation is essential depends in each case on the amount of information about the target that offerors need and on the extent to which they can obtain this information promptly without management's cooperation. Although competing bidders may often be able to come forward on their own, in many cases management's solicitation is likely to be helpful or even crucial for the facilitation of competing bids.

Thus, management often can make a desirable use of the power to auctioneer, either by actually facilitating competing bids or by employing the threat of auctioneering to bargain for a higher premium in a negotiated acquisition. That management can use a specific power in a desirable way, however, does not necessarily mean that it will elect to do so. Therefore, it is necessary to examine whether the possibility of managerial abuse may provide a reason for denying management the power to auctioneer.

Management's self-interest may affect its use of the auctioneering power in two ways. First, management may solicit a bid from a particular "white knight" not out of concern for the takeover's premium, but out of self-interest. The "white knight" may have promised to retain the management (either in return for the management's cooperation or for genuine business reasons) or to present it with some other personal benefits. But regardless of the management's motives, it performs a desirable role whenever it solicits a competing bid. As long as management cannot obstruct other contenders, the "white knight" will win the contest only if it is willing to pay the largest premium. Thus, the possibility that management's auctioneering will be motivated by self-serving preference among potential acquirers is not a ground for concern.

The second way in which management's self-interest may affect its use of the power to auctioneer is more troubling. Management that is negotiating with a prospective acquirer may agree to abstain from soliciting competing bids solely in return for the promise of personal benefits. In this case management's power to auctioneer does not, of course, serve any useful purpose. It should be emphasized, however, that the self-serving management can do nothing more than be passive; this cannot, in comparison with a situation in which management is required to be passive, reduce the premium shareholders will receive or lead to a less efficient allocation of the target's assets.

Clearly, the power to auctioneer would not serve its in- 
tended purpose if managements used it solely to extract personal benefits in return for abstaining from auctioneering. This Comment recommends that management be allowed to auctioneer, however, because there are reasons to expect management in a significant number of cases to use its power, at least partially, in a desirable way. In the face of an unsolicited tender offer, management may well elect to solicit a competing bid, either because of the incentives it has to increase the firm's value or because an acquisition by a particular "white knight" serves its self-interest better than one by the initial offeror. And in a negotiated acquisition, management may, because of the incentives to increase the firm's value, use the threat of auctioneering at least in part to bargain for an increased premium. Finally, although a duty to look for better offers in the face of a takeover bid would be difficult to enforce, imposing such a duty may further increase the frequency with which managements make a desirable use of the power to auctioneer. 